\title{
One Big Happy Family Perceptions of Inter-Group Relations between Jewish and Arab Nursing Students within and Outside a Natural Joint Environment
}

\author{
Dorit Hadar-Shoval*, Hadas Morag \\ The Max Stern Yezreel Valley College, Moledet, Israel \\ Email: *Dorith@yvc.ac.il
}

How to cite this paper: Hadar-Shoval, D., \& Morag, H. (2017). One Big Happy Family Perceptions of Inter-Group Relations between Jewish and Arab Nursing Students within and Outside a Natural Joint Environment. Psychology, 8, 1532-1545. https://doi.org/10.4236/psych.2017.810102

Received: March 15, 2017

Accepted: August 13, 2017

Published: August 16, 2017

Copyright $\odot 2017$ by authors and Scientific Research Publishing Inc. This work is licensed under the Creative Commons Attribution International License (CC BY 4.0).

http://creativecommons.org/licenses/by/4.0/

\begin{abstract}
The study focuses on perceptions of inter-group relations among Jewish and Arab nursing students in Israel. The study aimed at discovering whether these perceptions were affected by the environment in which they were examined. The results show that environment has an impact on perceptions of intergroup relations. In a natural environment where cooperation between individuals from different social groups is necessary, the relations were perceived as harmonious. On the other hand, in an environment that emphasizes the unique identity of each group, the relations were perceived as conflictual. These findings can be explained as reflecting the one big happy family perceptual bias. This bias may provide a basis for understanding inter-group conflict intervention processes among groups in conflict that operate together. The findings have professional implications for intervention processes implemented among heterogeneous multicultural teams in conflict situations.
\end{abstract}

\section{Keywords}

Inter-Group Relations, Jewish-Arab Relations, Group Conflict, Conflict Intervention, Perceptual Biases

\section{Introduction}

The present study focused on relations between groups operating in situations of conflict. The research attempts to understand the psychological processes underlying interpersonal relations between individuals working in heterogeneous teams in a natural environment marked by ongoing conflict. It was conducted 
among Jewish and Arab nursing students attending an Israeli academic institution.

Nursing professionals worldwide are highly heterogeneous (Likupe, 2015). Indeed, a large percentage of those working in this field are immigrants (Aboderin, 2007; Arieli \& Hirschfeld, 2013). Heterogeneous groups operating in a natural environment (Valentine, 2008) must often face challenges associated with team building, determination of group social norms and group cohesion (Allport, 1997; Wagner, Tropp, Finchilescu, \& Tredoux, 2009). Studies show that such challenges may affect how the group functions as a whole as well as how its members function specifically as individuals (Mallett, Akimoto, \& Oishi, 2016). These challenges are all the more consequential when the small group comprises individuals from larger groups engaged in an ongoing conflict (Azar, 1990), such as the Arab-Israeli conflict. An ongoing conflict is one that is absolute and all encompassing. It pervades the social fabric of the sides involved and forces itself on individuals and institutions alike (Bar-Tal, 2007; Rouhana \& Bar-Tal, 1998). The interactions between members of groups living in the shadow of such conflicts are often marked by low empathy (Stephan \& Stephan, 2001). There is often a sharp division into in-groups and out-groups based on a single group identity (Brewer, 1986), accompanied by attribution of negative stereotypes and behaviors biased in favor of the in-group (Abrams \& Hogg, 1990; Tajfel \& Turner, 1986).

\section{Intervention in Inter-Group Encounters}

Different intervention strategies have been developed in an attempt to address the challenges posed by inter-group conflict situations. These different intervention of inter-group conflict strategies can be positioned along a continuum. At one end of this continuum, the point of departure for the inter-group encounter is conflictual. The occurrences during the encounter are group occurrences with sociopolitical interpretations that are unequivocally tied to the outside reality. The group participants are perceived as representing two different national ethnic groups engaged in a struggle. The power relations between the groups are not symmetric. One group, the controlling majority, feels superior to the other group, while those in the minority group are marked by feelings of inferiority (Oasis of Peace, 2008; Suleiman, 2004). In this intervention strategy, group counseling typically focuses on the ethno-national group identity, shoving aside other identity components to the point of silencing or relinquishing the individual's unique voice. Such intervention subjugates the individual to the group and thus clarifies and sharpens the inter-group conflict, the power relations and the subjugation of one group by the other (Halabi, 2004; Oasis of Peace, 2008).

At the other end of this continuum, the inter-group encounter is based upon discussion that strives for coexistence, relates to group members as individuals and emphasizes the human common denominator. The group discourse stresses individuals and their inner world and disregards the group and social implica- 
tions of the encounter, for example hobbies, ambitions in life, interests (Pettigrew \& Tropp, 2006; Pettigrew \& Tropp, 2008). Group counseling in this intervention strategy typically stresses personal and emotional aspects and expressions of human suffering and directs interpretations toward content that is psychologically and introspectively beneficial to the group. The external sociopolitical reality serves as decoration for the human drama taking place within the group. Thus, the voices heard in the group are exclusively attributed to specific participants and explained as part of their unique characteristics rather than as attributes of the inter-group discourse. The spotlight is on the individuals comprising the group, with the components of group identity relegated to the margins of the discourse (Maoz, 2004).

These strategies are not necessarily contradictory despite the different means of action deriving from them. They are grounded in shared assumptions, perhaps due to the fact that in most cases the intervention moderators are from the fields of clinical psychology and group counseling. These assumptions emerge from the work of Bion (Bion, 1962; Bion, 1965; Bion, 1961). The first assumption is based on the notion that human beings are social creatures that conduct their lives in groups. The second assumption sees the group as an entity that stands on its own and not merely as the sum of all its parts. According to the third assumption, the group contains covert components that affect how it functions. According to the fourth assumption, everything that takes place in the group's "here and now"-in its current reality-is meaningful. Bion (Bion, 1961) claims that like individuals, groups also develop mechanisms to defend them against difficult emotions that are too threatening or too painful to acknowledge. These emotions are liable to develop in response to external or internal threats. One of the major defense mechanisms is denial, which pushes thoughts, feelings and experiences beyond the realm of consciousness because they arouse too much anxiety. In the two intervention strategies described above, denial plays a significant role in the group process. In the conflictual strategy, denial finds expression in the participants' refusal to talk about the inter-group conflicts or even to admit to their existence (Oasis of Peace, 2008; Suleiman, 2004). In the discussion strategy, the participants express denial by not agreeing to engage in introspection and critical self-examination of the psychological mechanisms underlying their behavior as a group (Maoz, 2004).

\section{The One Big Happy Family Bias}

The assumptions underlying the group counseling strategies described above served as the basis for the decision to embed Jewish-Arab discussion groups into the formal nursing curriculum at an Israeli academic institution. These groups were designed to provide a discussion sphere where individuals from both sides could engage in communication on highly volatile subjects deriving from the sociopolitical reality marking the Arab-Israeli conflict (Arieli \& Friedman, 2013). The study by Arieli and Friedman describes what happened when instructors 
tried to discuss the Arab-Jewish conflict in Israel or carry out an experiential introductory activity that involved dividing the participants into two groups-Jews and Arabs. The students voiced their objections, arguing that the instructors were trying to stir up conflict where none existed. They maintained that the group was cohesive and harmonious and that its members enjoyed excellent relations. Nevertheless, observations and data from a student survey revealed that in practice the students sat in two physically separated groups during courses and recesses (Arieli, Friedman, \& Hirschfeld, 2009). According to these authors, the members of the two groups were aware of their mutual differences yet refused to broach the issue or face or discuss the situation. The authors referred to this as a "one big happy family fantasy".

According to the assumptions underlying the inter-group intervention strategies, the one big happy family fantasy is evidence that the defense mechanisms of denial and objection are operating within the group's family fantasy framework in response to the group discourse. It is a behavioral expression of unconscious defense processes in the group that must be coped with so that relations among the members of the group can advance, develop and improve. Arieli and Friedman (2013) stress that these processes can be coped with in different ways deriving from varying theoretical approaches, such as the postcolonial approach and the negotiating reality approach. The difference lies in the nature of the action taken and not in the basic perception that these are processes that hinder the group and disrupt its advancement.

This research seeks to examine these processes identified by Arieli and Friedman using a different approach deriving from social cognition models. According to this approach, the one big happy family fantasy is not an expression of group defense mechanisms deriving from unconscious anxieties that hold back the group processes. Rather, it is an expression of a perceptual bias that serves human beings when they operate within a heterogeneous group composed of groups in conflict. Perceptual biases are part of human intuitive thought (Molden, Plaks, \& Dweck, 2006). They are a side effect of the strategies adopted by human consciousness to cope with complex information (e.g., disharmony in relationships generated by inter-group conflict situations). They are meant to enable us to cope and to explain the world around us in a way that can serve us (Molden \& Dweck, 2006). Perceptual biases are liable to lead us to perceive reality inaccurately (Gilovich, Griffin, \& Kahneman, 2002). Nevertheless, this inaccuracy enables us to cope with complexity and imbalance in our world (Kahneman, 2003). Hence, perceptual biases are likely to benefit rather than hinder the individual and the group.

Hence, this research is based on the assumption that one big happy family is not a fantasy but rather a perceptual bias. This bias serves those who are part of a group that consists of individuals affiliated with groups under conflict and that operates in a natural environment (Valentine, 2008). The key characteristic of this perceptual bias is that the inter-group relationship is perceived as harmo- 
nious and good, a perception that persists as long as the individuals operate within the joint environment. Once they emerge from this joint environment, the perception of relations between the respective sides changes as well, resuming its conflictual nature.

\section{Research Setting and Its Socio-Political Context}

Accordingly, the current study examined whether environment affected participants' perceptions of the relations between Jews and Arabs. Two environments marked by different characteristics were selected for this purpose. The first environment is the nursing department of an Israeli academic institution. This environment constitutes a meeting point for Jewish and Arab Israelis. Indeed, for some it is their first such encounter. In this environment, they find themselves under conditions of physical proximity, engage in joint activities and ongoing interactions and share goals based on academic requirements (Arieli \& Friedman, 2013). In addition, due to the nature of nursing studies, the students must consolidate a shared professional identity.

The second environment is the students' own home. This environment derives from the nature of relations between Jewish and Arab citizens in Israel, who live mostly in separate communities or neighborhoods and study in separate public education systems until the end of high school. Relations between the two groups have been heavily strained by Israel's ongoing conflict with the Palestinians and with much of the Arab world. Arab citizens of Israel often experience structural discrimination, socioeconomic inequality and exclusion relative to the Jewish majority. Fear, prejudice, ignorance and anxiety adversely affect each group's perceptions of and feelings toward the other (Bar-Tal, Halperin, \& Oren, 2010; Baum, 2006). In their own homes, Jewish and Arab students have practically no points of encounter. They have no common language, media exposure or identity discourse.

The purpose of this study was to examine whether the students' perceptions of their inter-group relations were affected by their environment. Will an environment marked by shared goals yield a perception of harmonious relations (one big happy family)? Will an environment marked by distinction and strangeness yield perceptions of conflictual relations?

Perceptions of the relations between the two sides can be manifested in different ways. To measure the quality of the shared relationship, the present study focused on the attribution of stereotypes (positive and negative) to members of the other group (Bar-Tal \& Labin, 2001; Teichman, Bar-Tal, \& Abdolrazeq, 2007) as well on the willingness to engage in social interaction with individuals from the other group (Bar-Tal \& Labin, 2001; Yuchtman-Yaar \& Inbar, 1986).

Accordingly, the research assumptions were as follows:

1) Perceptions of mutual negative stereotypes held by Arab and Jewish students in the nursing department will be less intense within the joint nursing school environment than outside the joint environment. 
2) Perceptions of mutual positive stereotypes held by Arab and Jewish students in the nursing department will be more intense within the joint environment than outside of it.

3) The students will be more willing to interact within the joint environment than outside of it.

4) The quality of Arab-Jewish relations will be perceived as higher in the nursing department than in Israel in general.

\section{Method}

\subsection{Participants}

The research participants included 182 undergraduate students (freshmen and seniors) enrolled in the Department of Nursing, Max Stern Yezreel Valley College, Israel. Of these, 111 were Jewish (7 males, 104 females) and 69 were Arab (22 males, 47 females). Students were asked whether they were willing to participate in the study as part of their coursework. The research assumptions were examined on 74 students who completed questionnaires handed out in their classes as well as questionnaires sent to their homes. The analysis of these assumptions included 28 Arab students (7 males, 21 females) and 46 Jewish students ( 4 males, 42 females). Out of 182 subjects, only about $40 \%$ completed the questionnaires in the college and at home. The reasons for this are the unwillingness of some of them to provide an e-mail address for continued engagement, as well as a decrease in the motivation to cooperate in completing the questionnaires at home. The dropout rate among Jews and Arabs was the same.

\subsection{Research Design}

The present study employed a mixed design with a within factor (at home college) and a between factor (Jewish, Arab).

The independent variables examined were:

1) The environment in which the participant completed the questionnairecollege/home (within factor).

2) Sector-Jewish/Arab (between factor).

The dependent variable in this study-perceptions of Arab-Jewish relationswas examined through several other variables:

1) Mutual Arab-Jewish stereotypes (positive and negative).

2) Willingness to engage in Jewish-Arab interaction (social distance).

3) Perceptions of Arab-Jewish relations in a joint academic department.

4) Perceptions of Arab-Jewish relations in Israel.

\subsection{Research Tools}

Data were collected using questionnaires that included the following sections:

Part A-Stereotypes (attribution of characteristics): The stereotypes questionnaire was developed by Teichman, Bar-Tal, \& Abdolrazeq (2007). The questionnaire examined the stereotypes held by all participants regarding members of the 
other group by means of a list of 18 adjectives, each rated on a scale from 1 to 5 . Participants were requested to estimate "what percent of Jews/Arabs in the college/in the country possess the following characteristics" $(0 \%$, none $=1 ; 25 \%$, a minority $=2 ; 50 \%$, half $=3 ; 75 \%$, most $=4 ; 100 \%$, all $=5$ ). The characteristics listed were both positive and negative: kind, clever, crooked, clean, engages in terrorism, lazy, pretty, cheeky, smelly, strong, educated, deceitful, cruel, loyal, hospitable, cowardly, friendly and violent. In the original questionnaire, the reliability index for the characteristics attributed to Jews yielded a Cronbach's alpha of 0.88 for negative characteristics and 0.84 for positive ones. The reliability index for characteristics attributed to Arabs yielded a Cronbach's alpha of 0.89 for negative characteristics and 0.82 for positive ones. In the present study, Cronbach's alpha was 0.859 for positive characteristics and 0.89 for negative characteristics.

Part B-Social Distance: The social distance questionnaire was borrowed from Sabo's questionnaire regarding foreign workers (2002) and was adapted for the present study, with Jewish students asked about Arab students and vice versa. The questionnaire included seven statements expressing different levels of willingness to interact with members of the other group, as in the following example: "I am willing to live next door to an Arab/Jewish student from the nursing department." Next to each item, participants had to rate their willingness to engage in this behavior on a scale from 1 to 10 , with 1 representing "definitely no" and 10 representing "definitely yes". On the original questionnaire, Cronbach's alpha was 0.89 , while on the present one, it was 0.807 . The grading of this questionnaire was determined by the calculated mean of each participant.

Part C-Perceptions of Jewish-Arab relations in Israel vs. at the College: This questionnaire was custom designed for the present study to measure two variables: students' perceptions of Arab-Jewish relations in Israel as a whole and their perceptions of these relations in the nursing department. The questionnaire comprised 12 statements pertaining to perceptions of Arab-Jewish relations at the college and in Israel and the differences between these perceptions. Participants were requested to rate their agreement with each statement on a scale ranging from 1 to 5 ( 5 = strongly agree, $4=$ slightly agree, $3=$ equally agree and disagree, 2 = slightly disagree, $1=$ totally disagree). Cronbach's alpha reliability computed for both variables was 0.83 .

Part D: Students were requested to answer the following open question: "In your opinion, do the relations between Arabs and Jews studying together in the nursing department differ from Jewish-Arab relations in general in Israel?"

\subsection{Procedure}

Questionnaires were distributed in June 2015, first in the classrooms on a school day and then, after two weeks, in the form of personal emails sent to each participant. The participants were told that the study sought to explore perceptions of Jewish-Arab relations, and it was made clear to them that they each must complete the questionnaire alone, without consulting any friends. Participants 
were assured that the questionnaires would remain anonymous and that there were no right or wrong answers. Upon completion of the questionnaire, they were asked to submit their email address as an indication of their consent for us to send them the second questionnaire, to be completed individually. We made it clear that the email address would be used exclusively for this purpose and would be deleted from our databases soon after the questionnaire was sent. In addition, participants were reassured that their answers would only be used for the purposes of the study.

Two weeks after the students completed the questionnaires in class in the nursing department, all those who agreed to continue participating in the study were each sent a second questionnaire by email. This questionnaire was to be answered individually, at home.

\subsection{Statistical Analysis}

We conducted internal reliability tests in each questionnaire, values were satisfying (Cronbach's $\alpha=0.80$ and above). Following this, we conducted a two-way ANOVA for within group (at home, college) $\mathrm{x}$ between group (Jewish, Arab) for the "positive stereotypes", "negative stereotypes", "social distance", and the "perceptions of Jewish-Arab relations in Israel vs. at the college".

\section{Results}

This study set out to examine whether perceptions of a current close relationship were affected by the environment surrounding the relationship. The research assumptions posited that an environment marked by common goals should lead to a good, harmonious perception of relations (one big happy family), while an environment marked by separation and alienation between the groups would lead to perceiving these relations as conflictual. These findings are summarized in Table 1.

The first research assumption maintained that perceptions of mutual negative stereotypes held by Arab and Jewish students in the nursing department would be less intense within the joint nursing school environment than outside the joint environment. This assumption was examined using a within-subject repeated measures analysis of variance, which yielded a significant difference of [F $\left.(1.72)=14.332, p<0.005, \eta_{p}^{2}=0.17\right]$. The mean of negative stereotypes in class $(\mathrm{M}=2.08, \mathrm{SD}=0.64)$ was lower than the mean of negative stereotypes at home $(\mathrm{M}=2.31, \mathrm{SD}=0.59)$. No interaction was found between sector (Jewish and Arab) and the measure of negative stereotypes at home and in class $[\mathrm{F}(1.72)=$ $2.179, \mathrm{n} . \mathrm{s}]$.

The second research assumption maintained that perceptions of mutual positive stereotypes held by Arab and Jewish students in the nursing department would be more intense within the joint environment than outside of it. This assumption was examined using a within-subject repeated measures analysis of variance, which yielded a significance difference of $[\mathrm{F}(1.72)=6.576, p<0.05$, $\left.\eta_{p}^{2}=0.09\right]$. The mean of positive stereotypes in class $(\mathrm{M}=3.41, \mathrm{SD}=0.55)$ was 
Table 1. Research variables, means and standard deviations in both measurement environments.

\begin{tabular}{|c|c|c|c|c|c|c|c|}
\hline & \multicolumn{2}{|c|}{ In Class } & \multicolumn{2}{|c|}{ At Home } & \multirow[b]{2}{*}{ F-score } & \multirow[b]{2}{*}{ Significance } & \multirow[b]{2}{*}{$\eta_{p}^{2}$} \\
\hline & Mean & $\begin{array}{l}\text { Standard } \\
\text { Deviation }\end{array}$ & Mean & $\begin{array}{l}\text { Standard } \\
\text { Deviation }\end{array}$ & & & \\
\hline Negative stereotypes & 2.08 & 0.64 & 2.31 & 0.59 & 14.332 & $p<0.005$ & 0.17 \\
\hline Positive stereotypes & 3.41 & 0.55 & 3.28 & 0.46 & 6.576 & $p<0.05$ & 0.09 \\
\hline $\begin{array}{l}\text { Social interaction } \\
\text { willingness }\end{array}$ & 5.96 & 1.46 & 5.28 & 1.59 & 11.361 & $p<0.005$ & 0.14 \\
\hline Perception of relations & \multirow{3}{*}{\multicolumn{4}{|c|}{$\mathrm{M}=3.79, \mathrm{SD}=0.78$}} & & & \\
\hline in Department of & & & & & & & \\
\hline Nursing & & & & & 28.482 & $p<0.005$ & 0.28 \\
\hline $\begin{array}{l}\text { Perception of relations } \\
\text { in Israel }\end{array}$ & \multicolumn{4}{|c|}{$\mathrm{M}=3.21, \mathrm{SD}=0.74$} & & & \\
\hline
\end{tabular}

higher than the mean of positive stereotypes at home $(\mathrm{M}=3.28, \mathrm{SD}=0.46)$. No interaction was found between sector (Jewish and Arab) and the measure of positive stereotypes at home and in class $[\mathrm{F}(1.72)=0.258, \mathrm{n} . \mathrm{s}]$.

The third research assumption maintained that the students would be more willing to interact within the joint environment than outside of it. This assumption was examined using a within-subject repeated measures analysis of variance, which yielded a significant difference [F $\left.(1.72)=11.361, p<0.005, \eta_{p}^{2}=0.14\right]$. The mean of willingness to interact was higher in class $(\mathrm{M}=5.69, \mathrm{SD}=1.46)$ than the corresponding mean at home $(\mathrm{M}=5.28, \mathrm{SD}=1.59)$. No interaction was found between sector (Jewish and Arab) and the positive stereotype measure at home and in class $[\mathrm{F}(1.72)=1.892$, n.s $]$.

The fourth research assumption maintained that the quality of Arab-Jewish relations would be perceived as higher in the nursing department than in Israel in general. This assumption was examined using a within-subject repeated measures analysis of variance, which yielded a significant difference $[\mathrm{F}(1.72)=$ 28.482, $p<0.005, \eta_{p}^{2}=0.28$. The mean for perception of the quality of the relations $(\mathrm{M}=3.79, \mathrm{SD}=0.78)$ was higher in the nursing department than the mean in the country at large $(\mathrm{M}=3.21, \mathrm{SD}=0.74)$. No interaction was found between sector (Jewish and Arab) and the measure of positive stereotypes at home and in class $[\mathrm{F}(1.72)=0.03, \mathrm{n} . \mathrm{s}]$.

In addition, students were asked to respond to an open question. "In your opinion, do the relations between Arabs and Jews studying together in the nursing department differ from Jewish-Arab relations in general in Israel?" Of the 74 students who completed the questionnaire concerning the quality of JewishArab relations in the nursing department and in Israel, 53 answered the open question. Most of them (46 students) thought that indeed there was a difference between the quality of relations in Israel and those at the college, such that relations at the college were better than in the country at large. Here are some explanations provided for this difference: "Yes, I do see a difference... Arabs who 
study in the same department as me mostly come from better families..."; "They "make" us treat them nice at the college and there's no choice but to live in fake peace..."; "In the nursing department there's no such thing as Jewish and Arab, everyone is equal..."; "The nursing profession requires that the caregiver be open... with no prejudice or racism... regardless of religion, race or sex..."; "Relations in the nursing department are better, it is a bubble compared to what happens around the country"; "I've encountered some really good Jewish people, but also some who are not... almost all Jews in my department are kind"; "In the nursing department there is strong cooperation between the two sides, as well as love and brotherhood".

\section{Discussion}

The present study focused on perceptions of inter-group relations among Jews and Arabs operating together in a natural environment. The study set out to examine whether these perceptions were affected by the surrounding environment. Does an environment marked by common goals lead to perceiving these relations as harmonious (one big happy family), while an environment marked by group separation and alienation leads to a conflictual perception? Based upon this objective, we formulated four research assumptions, each exploring a different aspect of the perceived relations. All four research assumptions received research corroboration.

The study's results suggest that the thinking schemes employed by individuals who belong to groups under ongoing conflict (Azar, 1990) are subject to change according to the environment in which they operate. These are, in fact, different sets of schemes, each derived from the goals and demands posed to the individual by the environment.

In an environment where cooperation between individuals from different social groups is essential in the routine functioning of the individual and the group alike, the relations were perceived as harmonious. This was evident in the increase in positive perceptions (positive stereotypes) and the decrease in negative perception (negative stereotypes), as well is in the increased willingness to engage in social interaction among members of both groups.

On the other hand, in an environment that highlights the distinct identity of each group, thus intensifying the sense of difference and mutual alienation, the relations were perceived as conflictual. This was evident in the decrease in positive perceptions (positive stereotypes) and the increase in negative perceptions (negative stereotypes), as well as in the decreased willingness to engage in social interaction among members of both groups.

These findings are congruent with Arieli and Friedman's account (2013) of Arab-Jewish encounter groups for nursing students, including the reluctance of both Arab and Jewish participants to take part in these groups based on the claim that no difficulties or problems exist between the sides. In the study, the researchers referred to this process as the one big happy family fantasy. 
The present study contends that one big happy family is not a fantasy, but rather a perceptual bias. Perceptual biases enable us to face the world around us and explain it to ourselves in a way that may serve us (Gilovich et al., 2002). Perceptual biases may lead to an inaccurate grasp of reality. Nevertheless, they often constitute a mechanism that helps us deal with complexity and imbalance in this world (Kahneman, 2003).

The Jewish and Arab students had a harmonious perception of their mutual relationship in their academic setting, where they were required to cooperate and work together. This perception is neither resistance (Suleiman, 2004) nor repression (Halabi, Sonnenschein, \& Friedman, 2004). Rather, it is a perceptual mechanism that serves inter-group relations within a heterogenic group whose members are embroiled in an ongoing conflict. It comprises a set of thinking schemes employed within this framework and maintained as long as it serves the group members in their goal of working together. When the students left the academic environment and returned to their homes, they began employing a different set of schemes to interpret reality and perceive the inter-group relations. The fact that no differences emerged between Jews and Arabs serves to reinforce the argument that this mechanism is a perceptual bias. Perceptual biases mark all people, regardless of racial background, gender or other differentiating characteristics (Sharot \& Garrett, 2016).

\section{Implications for Practice}

These findings have important consequences for inter-group conflict interventions among groups that operate together in a natural environment (Valentine, 2008). As described in Friedman and Arieli (2013), setting up encounter and discussion groups is one of the strategies for dealing with the intensity of the inter-group conflict and for balancing the impact of outside events on the intergroup relationship. These groups usually emphasize the group identity and national identity of each side (in our case, Israeli and Palestinian identities) while pushing other identities and identifications to the margins of discussion (Maoz, 2004; Maoz, 2011). Such a strategy further underlines the inter-group conflict by highlighting relations of power and oppression and the lines separating the groups. This emphasis elicits thinking schemes that do not benefit members of either group when they are required to cooperate. Moreover, it threatens the sense of closeness and friendship maintained when national issues are not emphasized. This sense of closeness and friendship is the adhesive that allows these individuals to cooperate as a group. Attempts to hold such dialogue groups in a natural environment may do more harm than good if they ignore that members from both groups need a sense of being one big happy family within the joint environment. The prevalent tendency in "group cross-cultural counseling" is to see this perception as a manifestation of "resistance" (Halabi et al., 2004; Suleiman, 2004). Only when both sides acknowledge this resistance can real change and dialogue take place. This strategy can be important and facilitate a move 
forward among individuals from different national groups who choose to sit together and engage in dialogue. Yet among mixed groups that operate together and cooperate for work and professional purposes, such a strategy may compromise the adhesive that allows them to act together. Intervention in situations such as these should adopt the one big happy family bias as an important element of group functioning rather than as a stumbling block.

Based upon this study, we recommend further development and exploration of the one big happy family bias in different joint settings, such as other academic institutions and workplaces that involve mixed groups. In addition, and in accordance with the theoretical conceptualization of this bias, inter-group intervention processes should be developed for teams embroiled in situations of external crisis that involve increased conflict intensity. This may allow group members to maintain themselves on all three levels_as individuals, as group members with a common goal and as possessors of a distinct group identity-based on the understanding that the inner dialogue between these three identity components is a constitutive element in the functioning of individuals and groups alike.

\section{Conflict of Interest}

The research was conducted in Israel. The authors declare that there are no potential conflicts of interest with respect to the research, authorship, and/or publication of this article.

\section{References}

Aboderin, I. (2007). Contexts, Motives and Experiences of Nigerian Overseas Nurses: Understanding Links to Globalization. Journal of Clinical Nursing, 16, 2237-2245. https://doi.org/10.1111/j.1365-2702.2007.01999.x

Abrams, D., \& Hogg, M. (1990). Social Identification, Self-Categorization and Social Influence. European Review of Social Psychology, 1, 195-228.

https://doi.org/10.1080/14792779108401862

Allport, G. W. (1997). The Nature of Prejudice. Reading, MA: Addison-Wesley.

Arieli, D., \& Friedman, V. (2013). Negotiating Reality: Conflict Transformation in Natural Spaces of Encounter. The Journal of Applied Behavioral Science, 49, 308-332. https://doi.org/10.1177/0021886313485128

Arieli, D., \& Hirschfeld, M. J. (2013). Supporting Minority Nursing Students: 'Opportunity for Success' for Ethiopian Immigrants in Israel. International Nursing Review, 60, 213-220. https://doi.org/10.1111/inr.12016

Arieli, D., Friedman, V. J., \& Hirschfeld, M. J. (2009). The Establishment of an Academic Nursing Faculty: Action Research in Israel. International Nursing Review, 56, 299-305. https://doi.org/10.1111/j.1466-7657.2009.00709.x

Azar, E. E. (1990). The Management of Protracted Social Conflict: Theory and Cases. Dartmouth: Dartmouth Publishing Company.

Bar-Tal, D. (2007). Sociopsychological Foundations of Intractable Conflicts. American Behavioral Scientist, 50, 1430-1453. https://doi.org/10.1177/0002764207302462

Bar-Tal, D., \& Labin, D. (2001). The Effect of a Major Event on Stereotyping: Terrorist 
Attacks in Israel and Israeli Adolescents' Perceptions of Palestinians, Jordanians and Arabs. European Journal of Social Psychology, 31, 265-280.

https://doi.org/10.1002/ejsp.43

Bar-Tal, D., Halperin, E., \& Oren, N. (2010). Socio-Psychological Barriers to Peace Making: The Case of the Israeli Jewish Society. Social Issues and Policy Review, 4, 63-109. https://doi.org/10.1111/j.1751-2409.2010.01018.x

Baum, N. (2006). Social Work Practice in Conflict-Ridden Areas: Cultural Sensitivity Is Not Enough. British Journal of Social Work, 37, 873-891. https://doi.org/10.1093/bjsw/bcl050

Bion, W. R. (1961). Experiences in Groups and Other Papers. London: Tavistock Publication. https://doi.org/10.4324/9780203359075

Bion, W. R. (1962). Learning from Experience. London: Maresfield Reprints.

Bion, W. R. (1965). Transformations. London: Maresfield Reprints.

Brewer, M. B. (1986). The Role of Ethnocentrism in Intergroup Conflict. In S. Worchel, \& W. G. Austin (Eds.), Psychology of Intergroup Relations (pp. 88-102). Chicago, IL: Nelson-Hall.

Gilovich, T., Griffin, D., \& Kahneman, D. (Eds.) (2002). Heuristics and Biases: The Psychology of Intuitive Judgement. Cambridge: Cambridge University Press. https://doi.org/10.1017/CBO9780511808098

Halabi, R. (2004). Israeli and Palestinian Identities in Dialogue: The School for Peace Approach. New Brunswick, NJ: Rutgers University Press.

Halabi, R., Sonnenschein, N., \& Friedman, A. (2004). Liberate the Oppressed and the Oppressors: Encounters between University Students. Intergroup Conflict and Its Reduction: A Socialpsychological Perspective. In H. Rabah (Ed.), Israeli and Palestinian Identities in Dialogue: The School for Peace Approach (pp. 59-78). New Brunswick, NJ: Rutgers University Press.

Kahneman, D. (2003). A Perspective on Judgment and Choice. American Psychologist, 58, 697-720. https://doi.org/10.1037/0003-066X.58.9.697

Likupe, G. (2015). Experiences of African Nurses and the Perception of Their Managers in the NHS. Journal of Nursing Management, 23, 231-241.

https://doi.org/10.1111/jonm.12119

Mallett, R. K., Akimoto, S., \& Oishi, S. (2016). Affect and Understanding during Everyday Cross-Race Experiences. Cultural Diversity \& Ethnic Minority Psychology, 22, 237-246. https://doi.org/10.1037/cdp0000032

Maoz, I. (2004). Coexistence Is in the Eye of the Beholder: Evaluating Intergroup Encounter Interventions between Jews and Arabs in Israel. Journal of Social Issues, 60, 437-452. https://doi.org/10.1111/j.0022-4537.2004.00119.x

Maoz, I. (2011). Does Contact Work in Protracted Asymmetrical Conflict? Appraising 20 Years of Reconciliation-Aimed Encounters between Israeli Jews and Palestinians. Journal of Peace Research, 48, 115-125.

https://doi.org/10.1177/0022343310389506

Molden, D. C., \& Dweck, C. S. (2006). Finding “Meaning” in Psychology. American Psychologist, 61, 192-203. https://doi.org/10.1037/0003-066X.61.3.192

Molden, D. C., Plaks, J. E., \& Dweck, C. S. (2006). “Meaningful” Social Inferences: Effects of Implicit Theories on Inferential Processes. Journal of Experimental Social Psychology, 42, 738-752. https://doi.org/10.1016/j.jesp.2005.11.005

Oasis of Peace (2008). Rethinking the Work of the School for Peace: The Introduction of 
Post-Colonialist Literature. http://nswas.org/spip.php?article755

Pettigrew, T. F., \& Tropp, L. R. (2006). A Meta-Analytic Test of Intergroup Contact Theory. Journal of Personality and Social Psychology, 90, 751-783. https://doi.org/10.1037/0022-3514.90.5.751

Pettigrew, T. F., \& Tropp, L. R. (2008). How Does Intergroup Contact Reduce Prejudice? Meta-Analytic Tests of Three Mediators. European Journal of Social Psychology, 38, 922-934. https://doi.org/10.1002/ejsp.504

Rouhana, N. N., \& Bar-Tal, D. (1998). Psychological Dynamics of Intractable Ethnonational Conflicts: The Israeli-Palestinian Case. American Psychologist, 53, 761-770. https://doi.org/10.1037/0003-066X.53.7.761

Sharot, T., \& Garrett, N. (2016). Forming Beliefs: Why Valence Matters. Trends in Cognitive Sciences, 20, 25. https://doi.org/10.1016/j.tics.2015.11.002

Stephan, W. G., \& Stephan, C. W. (2001). Improving Intergroup Relations. Thousand Oaks, CA: Sage Publications.

Suleiman, R. (2004). Jewish-Palestinian Relations in Israel: The Planned Encounter as a Microcosm. Intergroup Conflict and Its Reduction: A Social-Psychological Perspective. In H. Rabah (Ed.), Israeli and Palestinian Identities in Dialogue: The School for Peace Approach (pp. 31-46). New Brunswick, NJ: Rutgers University Press.

Tajfel, H., \& Turner, J. (1986). An Integrative Theory of Intergroup Conflict. In W. G. Austin, \& S. Worchel (Eds.), Psychology of Intergroup Relations (pp. 7-24). Monterey, CA: Brooks Cole.

Teichman, Y., Bar-Tal, D., \& Abdolrazeq, Y. (2007). Intergroup Biases in Conflict: Reexamination with Arab Pre-Adolescents and Adolescents. International Journal of Behavioral Development, 31, 423-432. https://doi.org/10.1177/0165025407081470

Valentine, G. (2008). Living with Difference: Reflections on Geographies of Encounter. Progress in Human Geography, 32, 323-337. https://doi.org/10.1177/0309133308089372

Wagner, U., Tropp, L., Finchilescu, G., \& Tredoux, C. (Eds.) (2009). Improving Intergroup Relations: Building on the Legacy of Thomas F. Pettigrew. Hoboken, NJ: WileyBlackwell.

Yuchtman-Yaar, E., \& Inbar, M. (1986). Social Distance in the Israeli-Arab Conflict; A Resource-Dependency Analysis. Comparative Political Studies, 19, 283-316. https://doi.org/10.1177/0010414086019003001

Scientific Research Publishing

Submit or recommend next manuscript to SCIRP and we will provide best service for you:

Accepting pre-submission inquiries through Email, Facebook, LinkedIn, Twitter, etc. A wide selection of journals (inclusive of 9 subjects, more than 200 journals)

Providing 24-hour high-quality service

User-friendly online submission system

Fair and swift peer-review system

Efficient typesetting and proofreading procedure

Display of the result of downloads and visits, as well as the number of cited articles

Maximum dissemination of your research work

Submit your manuscript at: http://papersubmission.scirp.org/

Or contact psych@scirp.org 